\title{
Pengembangan Modul Seni Kreatif dalam Memberikan Layanan Bimbingan Konseling Inovatif
}

\author{
Alfi Rahmi \\ Institut Agama Islam Negeri (IAIN) Bukittinggi \\ alfi.rahmi79@gmail.com \\ Nurhasnah \\ Institut Agama Islam Negeri (IAIN) Bukittinggi \\ hasnahalso@gmail.com
}

\begin{abstract}
This study aims to develop a creative arts module in counseling so that there are innovations in guidance and counseling services. Visual arts are one of the creative arts in counseling that can help someone relax the burdens they feel in everyday life. Visual Arts in creative counseling can be given to clients who have difficulty verbally expressing their problems. Visual arts can be an alternative for Guidance and Counseling Teachers in schools in carrying out counseling services. This research is a type of development research using the Borg and Gall model. The steps taken are collecting initial information, planning, product development, product validation and testing, product revision, field testing and product end revision. Product trials were carried out on Guidance and Counseling Teachers at the junior high school level in East Agam and in Focus Group Discussion (FGD) activities. The results of the phase I module validation with a value of 15.8 where the module still needs to be revised including discussion of module content, as well as more interesting module design. Then the results of the practicality test with a value of Practical Enough, namely 3.8. The results of the phase II module verification with a value of 16.6 indicate that the module is suitable for use by the Guidance and Counseling Teacher and the results of the practicality test 4.01 .
\end{abstract}

Keywords: Creative Arts Module, Visual Arts, Guidance and Innovative Counseling 


\begin{abstract}
Abstrak
Penelitian ini bertujuan untuk mengembangkan modul seni kreatif dalam konseling agar terdapat inovasi dalam pelayanan bimbingan dan konseling. Seni visual merupakan salah satu seni kreatif dalam konseling dapat membantu seseorang untuk melakukan relaksasi terhadap beban yang dirasakan dalam kehidupan seharai-hari. Seni Visual dalam konseling kreatif dapat diberikan kepada klien yang mengalami kesulitan dalam mengungkapkan permasalahannya secara verbal. Seni visual dapat menjadi alternatif bagi Guru Bimbingan dan Konseling di sekolah dalam melaksanakan pelayanan konseling. Penelitian ini termasuk jenis penelitian pengembangan dengan model Borg and Gall. Langkah yang dilakukan melalui pengumpulan informasi awal, perencanaan, pengembangan produk, validasi produk dan uji coba, revisi produk, uji coba lapangan dan revisi ahir produk. Ujicoba produk dilakukan kepada Guru Bimbingan dan Konseling Tingkat SLTP sederajat di Agam Timur dan kegiatan Focuss Group Discussion (FGD). Hasil validasi modul tahap I dengan nilai 15,8 dimana modul masih perlu direvisi meliputi pembahasan isi modul, serta desaign modul yang lebih menarik. Kemudian hasil uji paktikalitas dengan nilai Cukup Praktis yaitu 3.8. Hasil vaildasi modul tahap II dengan nilai 16.6 menunjukan bahwa modul layak digunakan oleh Guru Bimbingan dan Konseling dan hasil uji praktikalitas 4.01.
\end{abstract}

Kata kunci: Modul Seni Kreatif, Seni Visual, Layanan Bimbingan dan Konseling Inovatif

\title{
Pendahuluan
}

Terselenggaranya layanan bimbingan dan konseling yang professional didukung oleh kompetensi dari guru bimbingan dan konseling sebagai penyelenggara layanan. Salah satu kompetensi dasar yang mesti dimiliki oleh guru bimbingan dan konseling yaitu kompetensi profesional. ${ }^{1}$ Kompetensi professional mencakup penguasaan terhadap konsep dan praktis assessment dalam memahami kondisi, kebutuhan serta masalah konseling, menguasai akan kerangka teoritik dan praksis bimbingan dan konseling, memiliki kemampuan untuk merancang program bimbingan dan konseling, mampu mengimplementasikan program bimbingan dan konseling yang komprehensif, serta menilai proses dan hasil kegiatan bimbingan dan konseling, memiliki kesadaran dan komitmen etika professional, dan menguasai konsep dan praksis

1 Peraturan Menteri Pendidikan Nasional, 'Standar Kualifikasi Akademik dan Kompetensi Guru, Nomor 16 Tahun 2007 Tanggal 4 mei 2007', Journal of Chemical Information and Modeling, 2007. 
penelitian dalam bimbingan dan konseling. ${ }^{2}$

Penguasaan kompetensi professional guru BK dapat dilihat dari kemampuan guru BK dalam menerapkan aspek-aspek kompetensi tersebut dalam pelayanan konseling baik secara individual maupun kelompok. Kenyataan di lapangan tidak semua guru BK menguasai kompetensi professional secara utuh. Terdapat berbagai upaya untuk mengembangkan potensi guru BK agar memberikan dampak yang signifikan dalam pengembangan potensi peserta didiknya. Salah satu upaya yang dapat dilakukan melalui penerapan layanan bimbingan dan konseling melalui konseling inovatif.

Konseling Inovatif melalui seni kreatif merupakan suatu bentuk paradigma baru dalam layanan konseling dari metode konvensional. Konseling inovatif dengan berbantuan seni kreatif menjadi suatu metode baru dalam layanan konseling dan akan memberikan dampak kebermaknaan bagi klien. ${ }^{3}$

Seni Kreatif sebagai bagian dari konseling ekspresif yang akan menjadi sarana untuk melepaskan emosi yang ada dalam diri seseorang sehingga membuat individu lebih peka terhadap diri sendiri dan dapat membantu individu untuk mengembangkan potensi dirinya lebih baik lagi. ${ }^{4}$ Penggunaan konseling ekspresif dan kreatif dapat menjadi solusi dalam memperdalam proses konseling untuk melakukan proses diagnosis, eksplorasi masalah klien dan penyelesaian masalah klien. ${ }^{5}$ Perpaduan Seni dalam konseling menjadi terapi bagi individu. Terapi seni sebagai cara untuk menolong individu yang mengalami kondisi distress dengan menggunakan seni sebagai media komunikasi antara individu dengan terapis. ${ }^{6}$ Melalui terapi seni akan menambah wawasan tentang kompleksitas hubungan antara fisiologis, emosi dan gambar sebagai bagian dari intervensi efektivitas yang telah dilakukan. ${ }^{7}$ Proses kreatif yang terlibat dalam artistic mengekspresikan diri akan membantu orang untuk menyelesaikan konflik, mengembangkan keterampilan interpersonal, mengelola perilaku, mengurangi stress, dan meningkatkan harga diri sehingga memperoleh wawasan. ${ }^{8}$

Menurut Glading bentuk seni kreatif dalam konseling antara lain seni

2 Depdiknas, Penataan Pendidikan Profesional Konselor Dan Layanan Bimbingan Dan Konseling DI Jalur Pendidikan Formal, 2008.

3 Annisa Sofiana Wahyu Nanda Eka Saputra, 'Konseling Inovatif Berbantuan Seni Kreatif, Prosiding Seminar Nasional Bimbingan Dan Konseling, 2017.

${ }^{4}$ Karyanti, Dance Counseling, 1st edn (Yoqyakarta: Deepublish, 2018).h.37

${ }^{5}$ Husni Abdillah, 'Penggunaan Seni Ekspresif Dalam Bimbingan Dan Konseling', Jurnal Bimbingan Dan Konseling, Asosiasi Bimbingan Dan Konseling Indonesia Pengurus Daerah Provinsi Jawa Timur, 1.1 (2015), 43-49.

${ }^{6}$ Dede Rahmat Hidayat, Konseling Di Sekolah Pendekatan-Pendekatan Kontemporer (Jakarta: Prenadamedia Group, 2018).

${ }^{7}$ Cathy Molchiadi, Hanbook of At Therapy (New York: Guilford Press, 2003).

${ }^{8}$ Chandrania Fastari, ART PSYCHOTHERAPY GAMBAR. 
visual ${ }^{9}$. Menurut Gladding bahwa seni visual dapat membantu peserta didik mengungkapkan permasalahan melalui proses mewarnai, proses menggambar dan mematung. Konseling ini dapat dilakukan untuk peserta didik yang mengalami kesulitan mengungkapkan permasalahannya melalui verbal dan dapat mengungkapkan permasalahannya melalui gambar yang berbentuk lukisan. Penelitian terdahulu oleh Mukhtar yang menghasilkan bahwa art therapy atau terapi seni efektif untuk meningkatkan keterampilan sosial pada anak yang mengalami gangguan. ${ }^{10}$ Kemudian penelitian yang dilakukan oleh Bagus Mahardika bahwa pemanfaatan metode art therapy merupakan solusi dalam meningkatkan kecerdasan pada siswa terutama pada usia anak-anak. ${ }^{11}$

Menurut Gladding dalam Said Alhadi dan Wahyu Nanda Eka Saputra menyatakan bahwa terdapat lima premis penggunaan seni visual dalam konseling yaitu:

1. Seni visual merupakan gambaran alam bawah sadar seseorang dan melalui seni visual akan membantu individu mengungkapkan konflik rahasia yang tidak mereka ungkapkan pada awal pertemuan.

2. Seni visual merupakan lambing perasaan yang ditampilkan dengan cara yang unik, nyata, dan kuat.

3. Seni visual mampu memberikan inspirasi bagi seseorang dan membantu orang menjadi lebih terhubung dengan sisi transenden dan pertumbuhan kepribadian mereka.

4. Seni visual akan membantu konseling terutama pada anak-anak merasa nyaman dalam pelaksanaan konseling.

5. Seni visual dapat dikombinasikan dengan seni kreatif lainnya seperti melalui gerakan, melalui menulis kreatif, dan imagery. ${ }^{12}$

Teknik seni visual di atas dapat dilaksanakan sesuai dengan karakteristik masalah yang dialami klien. Klien dapat mengeksplorasi dan perasan meraka melalui visual yang ditampilkannya. Pelaksanaan seni visual dalam konseling dapat diselenggarakan melalui layanan konseling perorangan maupun kelompok. Kompetensi umum yang mesti dikuasai guru BK dalam melaksanakan terapi seni adalah memiliki kemampuan penampilan menarik dan menyenangkan menampilkan tindakan yang cerdas, kreatif, inovatif dan produktif serta

${ }^{9}$ Samuel T. Gladding, The Creative Arts in Counseling: Fourth Edition, The Creative Arts in Counseling: Fourth Edition, 2015 < https://doi.org/10.1002/9781119221630>.

10 Desvi Yanti Mukhtar, 'Efektivitas Art Therapy Untuk Meningkatkan Keterampilan Sosial Pada Anak Yang Mengalami Gangguan Perilaku', 2005.

${ }^{11}$ Dede Rahmat Hidayat.

12 Said Alhadi and Wahyu Nanda Eka Saputra, 'Integrasi Seni Kreatif Dalam Konseling Dengan Pemanfaatan Seni Visual', JURNAL FOKUS KONSELING, 2017 <https://doi.org/10.26638/jfk.384.2099>. 
bersemangat dan disiplin, peka dan berempati serta memiliki kemampuan komunikasi yang efektif. ${ }^{13}$ Kreativitas dalam konseling merupakan hal yang esensial dimana konselor perlu menciptakan suasana yang nyaman dan aman sehingga mendukung klien mampu secara kreatif mengkaji masalahnya dan mengevaluasi beragam solusi. ${ }^{14}$

Mengingat besarnya manfaat dari seni kreatif ini dalam membantu guru bimbingan dan konseling menyelenggarakan layanan, maka perlu suatu upaya pemberian bantuan dalam pengembangan kompetensi guru bimbingan dan konseling agar lebih kreatif dalam menyelenggarakan layanan bimbingan dan konseling melalui penerapan seni kreatif dalam konseling. Namun tidak semua guru bimbingan dan konseling memiliki kemampuan dalam melaksanakan seni visual dalam konseling. Berdasarkan fenomena di lapangan bahwa Guru bimbingan dan konseling mengalami kesulitan dalam menghadapi karakteristik klien yang pendiam dan tidak mau menceritakan permasalahan yang sedang dihadapinya. Dalam pelaksanaan konseling perorangan klien lebih banyak diam dan merasa takut untuk menceritakan masalahnya sehingga guru bimbingan dan konseling lebih aktif dalam proses konseling. Untuk menghadapi karakteristik klien yang seperti ini dibutuhkan keterampilan dari guru bimbingan dan konseling. Guru BK juga belum menggunakan berbagai media kreatif dalam membantu penyelenggaraan konseling. Guru BK belum mempunyai panduan untuk dijadikan pedoman dalam mengembangkan layanan bimbingan dan konseling yang kreatif dan inovatif. Guru BK juga belum memiliki keterampilan khusus untuk mengembangkan modul untuk panduan dalam menyelenggarakan layanan. Berdasarkan kondisi awal ini peneliti mengidentifikasi permasalahan kurangnya pemahaman guru bimbingan dan konseling dalam menyelenggarakan layanan bimbingan dan konseling yang kreatif dan inovatif, guru bimbingan dan konseling belum menyusun dan memanfaatkan modul untuk memberikan layanan bimbingan dan konseling yang kreatif dan inovatif.

Penelitian ini merupakan jenis penelitian pengembangan dengan menggunakan pendekatan model Borg and Goll. Penelitian Pengembangan ini akan menemukan pengetahuan baru untuk menjawab pertanyaan khusus tentang masalah praktis. ${ }^{15}$ Peneliti akan mengembangkan sebuah produk Modul Seni Visual Dalam Konseling yang merupakan bagian dari Konseling Kreatif. Menurut Borg dan Gall dalam I Made Tegeh dkk terdapat beberapa langkah dalam siklus R \& D (Research and Development) untuk mengembangkan suatu produk adalah sebagai berikut: ${ }^{16}$

\footnotetext{
${ }^{13}$ Cathy Molchiadi.

14 A. A Rahmadian, 'Kreativitas Dalam Konseling' (Bandung: UPI, 2011).

${ }^{15}$ Endang Widi Winarni. Teori Dan Praktik Penelitian KUantitatif, Kualitatif, PTK dan R\&D. Bumi Aksara, Jakarta. 2018, h. 249

${ }^{16}$ I Made Tegeh dkk, Model Penelitian Pengembangan (Yoqyakarta: Graha Ilmu, 2014).h.17
} 
1. Pengumpulan informasi yang meliputi kajian pustaka, pengamatan di kelas dan penyiapan laporan

2. Perencanaan untuk mendefenisikan keterampilan, tujuan dan tes skala kecil yang dapat dilakukan

3. Mengembangkan bentuk pendahuluan produk yang meliputi persiapan materi pembelajaran, handbook dan alat evaluasi

4. Uji lapangan pada 1 sampai 3 sekolah dengan menggunakan 6 sampai 12 subjek dengan menggunakan format Wawancara, observasi dan kuesioner pengumpulan data dan analisis data.

5. Revisi produk utama sesuai dengan saran hasil uji lapangan persiapan.

6. Uji lapangan utama yang dilakukan pada 5 sampai 15 sekolah dengan 30 sampai 100 subjek.

7. Revisi produk sesuai yang disarankan oleh hasil uji lapangan utama.

8. Uji lapangan operasional yang dilakukan pada 10 sampai 30 sekolah meliputi 40 sampai 200 subjek. Wawancara, observasi dan kuesioner pengumpulan dan analisis data.

9. Revisi produk akhir sesuai yang disarankan oleh hasil uji lapangan operasional.

10. Penyebaran dan serta pelaporan produk pada pertemuan professional dalam jurnal ilmiah.

Prosedur atau langkah-langkah pengembangan yang digunakandalam penelitian ini adalah sebagai berikut:

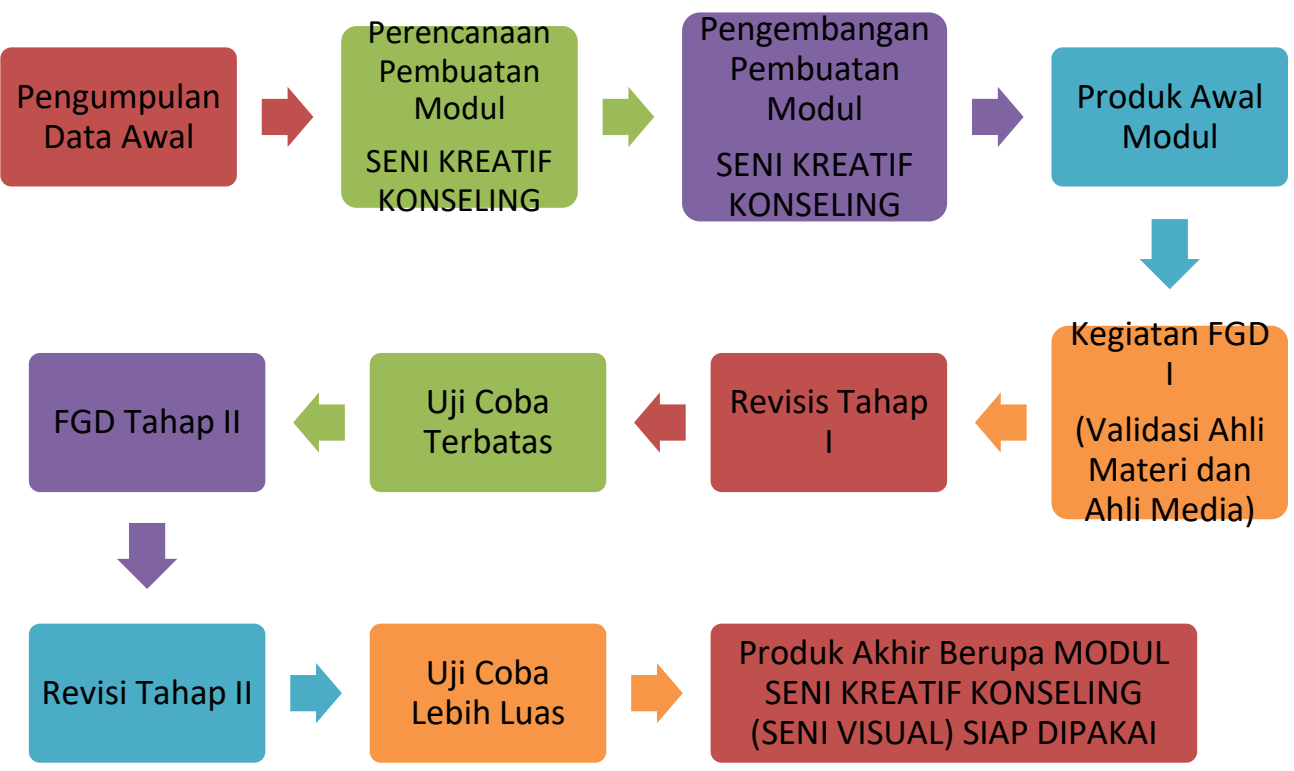




\section{Hasil dan Pembahasan}

\section{Tahap Pengumpulan Informasi Sebagai Data Awal}

Pertama sekali dilakukan pengumpulan data mengenai pemahaman guru Bimbingan dan Konseling mengenai teknik konseling yang telah dilakukan dalam memberikan pelayanan konseling serta pengetahuan guru BK mengenai seni kreatif konseling. Tahap pengumpulan data dilakukan dengan cara studi lapangan dan studi pustaka. Studi lapangan untuk mengetahui pemahaman guru Bimbingan dan Konseling mengenai teknik konseling dalam memberikan pelayanan konseling serta pengetahuan guru BK mengenai seni kreatif konseling. Sebagai data awal pengumpulan informasi mengetahui pemahaman guru bimbingan dan konseling mengenai seni kreatif dalam konseling, maka dilakukanlah kunjungan ketiga sekolah. Adapun sekolah yang dikunjungi untuk mendapatkan informasi yaitu:

1. SMPN IV Koto dengan guru BK "YM"

2. SMPN I Ampek Angkek dengan guru BK "RY"

3. SMPN I Banuhampu dengan guru BK "PT

Berdasarkan informasi awal dari tiga sekolah dapat disimpulkan bahwa guru bimbingan dan konseling belum mengetahui tentang seni visual dalam konseling. Keterampilan konseling yang pernah dipakai dalam proses pemberian layanan yaitu teknik umum.

\section{Tahap Dalam Perencanaan}

Tahap Perencanaan bertujuan untuk menentukan urutan bahan materi Perencanaan kegiatan FGD dan uji coba skala kecil. Bahan yang terkumpul sebagai dasar pembuatan draft modul yang akan dibahan dalam kegiatan FGD. Peneliti merumuskan tujuan pengembangan yang akan dicapai dan mengumpulkan bahan pendukung modul. Adapun langkah-langkah yang dilakukan oleh peneliti yaitu:

a. Memilah materi yang akan dibuat dalam modul

b. Menentukan Judul Modul yaitu : Modul Seni Kreatif Konseling

c. Merancang draft awal modul seni kreatif konseling dengan desain produk sebagai berikut:

1) Desain Cover

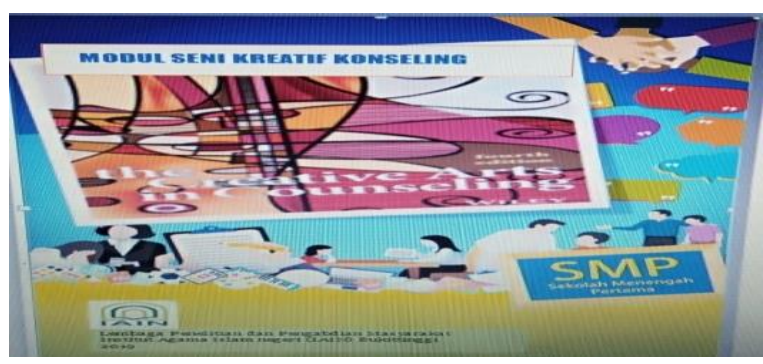


170 | Islamic Counseling: Jurnal Bimbingan dan Konseling Islam, Vol. 4, No. 2, 2020

2) Tampilan Daftar Isi

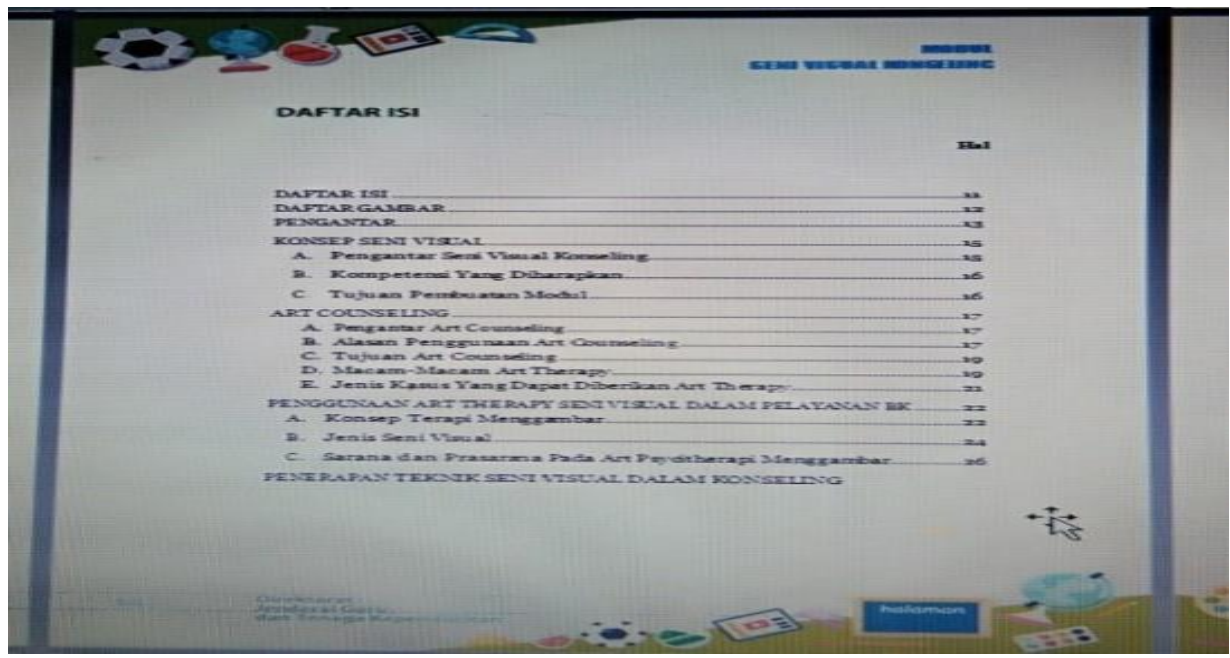

3) Desain Tampilan Antarmuka Materi

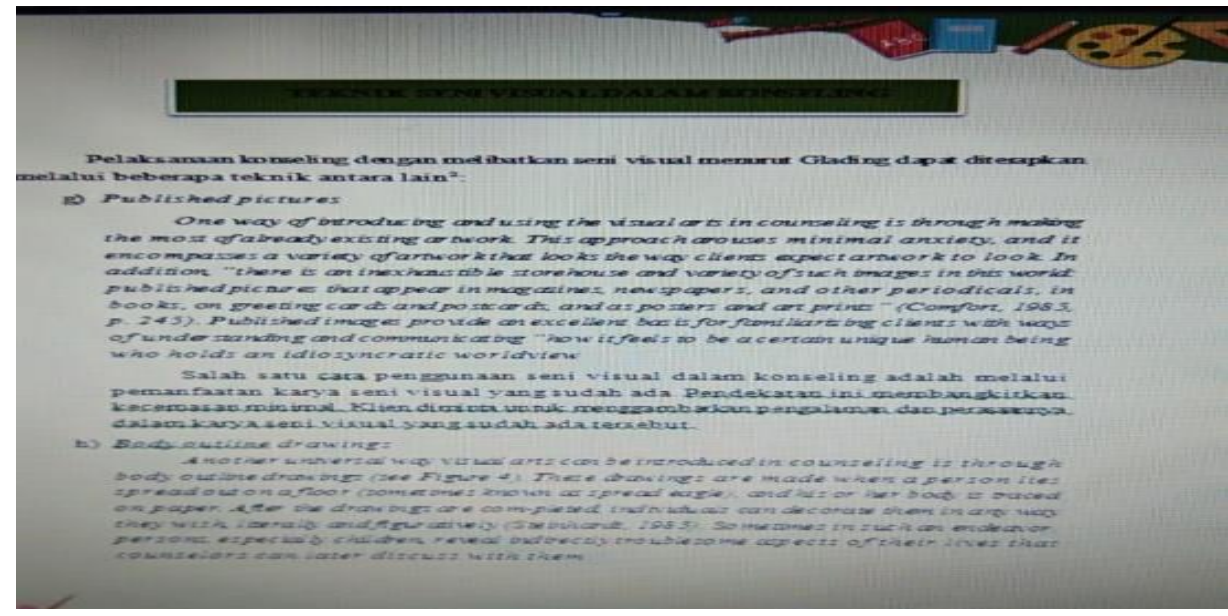

2. Tahap dalam pengembangan produk

Pengembangan Modul diawali dengan mengumpulkan sumber data, mengelola data yang didapatkan dan terakhir memproduksi bahan tersebut. Berdasarkan draft modul yang telah dibuat sebelumnya, maka dilakukanlah kegiatan Focus Group Discussion (FGD). Kegiatan FGD dilaksanakan tanggal 10 Oktober 2019 di Café Amelia. Kegiatan FGD dihadiri oleh 10 orang peserta yang terdiri dari Dosen Prodi BK, Guru BK dan Mahasiswa BK. dengan menghadirkan Narasumber dari Akademisi BK yaitu Bapak Ahmad Masrur Firosad, M.Pd dan peserta dari akademisi yaitu Dosen BK, Praktisi yaitu Guru BK, dan Mahasiswa BK. Hasil masukan dalam kegiatan FGD akan 
menyempurnakan produk awal sebelum di ujicobakan.

3. Tahap Validasi dan Uji Coba

Hasil revisi dari kegiatan FGD tahap I akan diujicobakan kepada Guru BK untuk 5 sekolah yaitu MTsN 6 Agam, Ponpes Parabek, MTI Candung, SMPN I Banuhampu, SMPN IV Koto. Kegiatan Uji Coba dilakukan utuk meminta tanggapan dan komentar mengenai kualitas dari Modul Seni Visual Konseling yang telah dikembangkan. Sasaran uji coba yaitu Guru Bimbingan dan Konseling yang diwakili masing-masing sekolah satu orang. Uji coba dilakukan kepada Guru BK dilakukan untuk melihat kelayakan isi yang dikembangkan. Berdasarkan uji coba disediakan beberapa fasilitas yaitu Kertas Gambar, Krayon, Pensil Warna dan Cat Air serta Kertas Marton. Adapun prosedur yang dilakukan yaitu:

a. Memperkenalkan Seni Visual dalam Konseling kepada Guru BK

b. Menjelaskan Konsep Seni Visual Dalam Konseling

c. Menjelaskan fungsi dari alat ayng disediakan

d. Memberikan contoh seni visual

e. Meminta guru BK untuk mempraktekan seni visual

Peneliti memberikan instrument untuk mengukur tingkat kevalidan dari produk yang dirancang. Berikut pada tabel 1 hasil validasi produk tahap awal.

Tabel 1 : Data Hasil Validasi Modul

\begin{tabular}{|c|c|c|c|c|}
\hline $\mathrm{No}$ & Aspek & Pernyataan & Rata-Rata & $\begin{array}{c}\text { Kriteria } \\
\text { Kevalidan }\end{array}$ \\
\hline \multirow[t]{2}{*}{1} & \multirow[t]{2}{*}{ Bahasa } & $\begin{array}{l}\text { Bahasa yang digunakan } \\
\text { dalam modul dapat } \\
\text { dipahami dengan } \\
\text { mudah }\end{array}$ & 4 & \multirow{5}{*}{$\begin{array}{l}\text { Modul } \\
\text { dapat } \\
\text { digunakan } \\
\text { sedikit } \\
\text { revisi } \\
\text { dengan } \\
\text { Nilai B }\end{array}$} \\
\hline & & $\begin{array}{l}\text { Modul Menggunakan } \\
\text { tata basaha yang baik } \\
\text { dan benar }\end{array}$ & 4 & \\
\hline \multirow[t]{2}{*}{2} & \multirow[t]{2}{*}{$\begin{array}{l}\text { Penggunaan } \\
\text { Istilah dan } \\
\text { Simbol }\end{array}$} & $\begin{array}{l}\text { Penggunaan istilah } \\
\text { dalam modul konsisten } \\
\text { antar bagian }\end{array}$ & 3.8 & \\
\hline & & $\begin{array}{l}\text { Penggunaan notasi atau } \\
\text { symbol dalam modul } \\
\text { konsisten antar bagian }\end{array}$ & 4 & \\
\hline \multicolumn{3}{|c|}{ Total Rata Keseluruhan } & 15,8 & \\
\hline
\end{tabular}

Peneliti juga memperhatikan saran yang diberikan oleh validator yang akan digunakan untuk menyempurnakan modul tahap akhir. Adapun saran yang dikemukakan oleh guru BK dalam instrument validasi yaitu: yaitu pembahasan isi modul lebih disederhanakan, materi yang disajikan dapat dilengakapi beserta 
contohnya, dan isi modul sangat bagus karena mampu dijadikan formula baru, desaign layoutnya perlu dibuat lebih menarik lagi.

Setelah uji Validitas Modul, kemudian dilanjutkan dengan uji praktikalitas modul dengan hasil pada tabel 2 sebagai berikut :

\section{Tabel 2 : Uji Praktikalitas Modul}

\begin{tabular}{|c|c|c|c|}
\hline $\mathrm{No}$ & Pernyataan & Rata-Rata & $\begin{array}{c}\text { Kriteria } \\
\text { Pratikalitas }\end{array}$ \\
\hline 1 & $\begin{array}{l}\text { Modul ini Mudah digunakan dan } \\
\text { dipahami }\end{array}$ & 4,2 & Praktis \\
\hline 3 & Modul ini Sangat berguna & 5 & Sangat Praktis \\
\hline 4 & $\begin{array}{l}\text { Modul ini sesuai dengan indikator } \\
\text { dan mudah dipahami }\end{array}$ & 4,2 & Praktis \\
\hline 5 & Modul ini tepat sasaran & 5 & Sangat Praktis \\
\hline 6 & Penyajian modul ini mudah dipahami & 4,6 & Praktis \\
\hline 7 & $\begin{array}{l}\text { Penggunaan buku modul } \\
\text { Pengembangan Seni Kreatif dalam } \\
\text { Konseling untuk Memperkuat } \\
\text { Keterampilan Konselor Memberikan } \\
\text { Layanan Bimbingan dan Konseling } \\
\text { yang Inovatif menumbuh } \\
\text { kembangkan kemampuan konselor }\end{array}$ & 4,2 & Praktis \\
\hline & Total rata-rata & 3.8 & Cukup Praktis \\
\hline
\end{tabular}

Hal ini telah dibuktikan oleh guru BK di sekolah bahwa siswa menjadi tertarik mengikuti kegiatan konseling karena merasakan rileks dalam kegiatan dan menyenangkan. Seni visual yang diminati siswa adalah menggambar bebas, sesuai dengan apa yang dirasakan dan dipikirkannya. Berdasarkan grafik di atas, maka dapat diambil kesimpulan bahwa produk yang dibuat sudah praktis.

4. Revisi Terhadap Produk

Berdasarkan hasil uji coba awal. Hasil uji coba lapangan tersebut diperoleh informasi kualitatif tentang program atau produk yang dikembangkan. Berdasarkan hasil uji coba kemudian masukan dari Guru BK, maka modul disempurnakan lagi dan dilakukan Focus Group Discussion II (FGD). FGD II ini juga menghadirkan Narasumber Ibu Zubaidah, M.Pd, Kons dan Dosen BK, Guru BK dan Mahasiswa BK. Hasil FGD II disempurnakan Modul untuk diujicobakan pada sekolah yang lebih luas yaitu 7 sekolah yaitu MTsN 6 Agam, Ponpes Parabek, MTI Candung, SMPN I Banuhampu, SMPN IV Koto, MTsN 2 Agam, Ponpes Diniyah Pasie.

Berdasarkan data validitas seperti tercantum di atas, maka modul disempurnakan. Peneliti merangkum semua masukan dari hasil FGD dan uji 
coba lapangan kemudian merancang penyempurnaan modul. Peneliti merevisi rancangan Modul begitu juga dengan desain atau layout dari modul tersebut.

a. Desain Cover

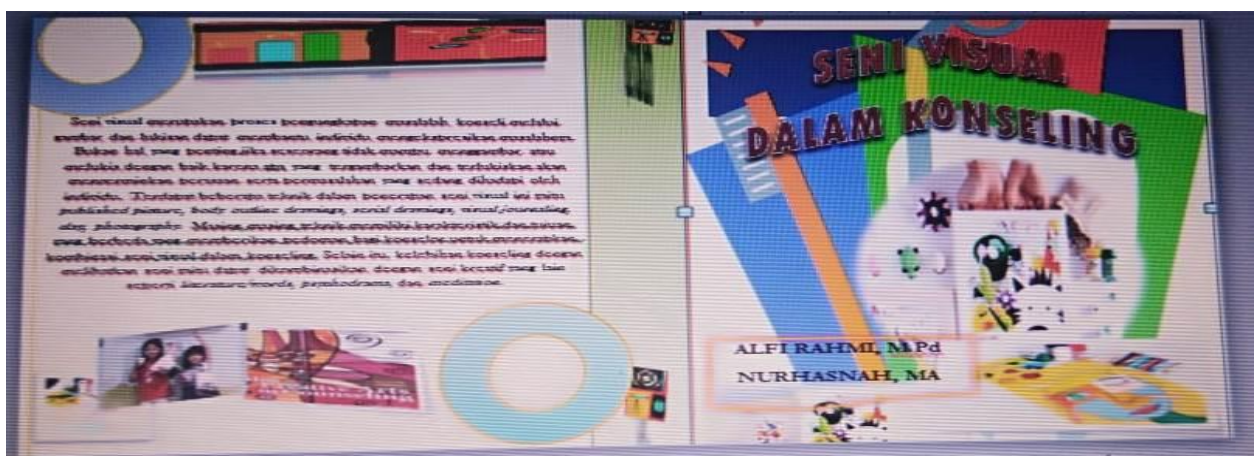

b. Cover Dalam

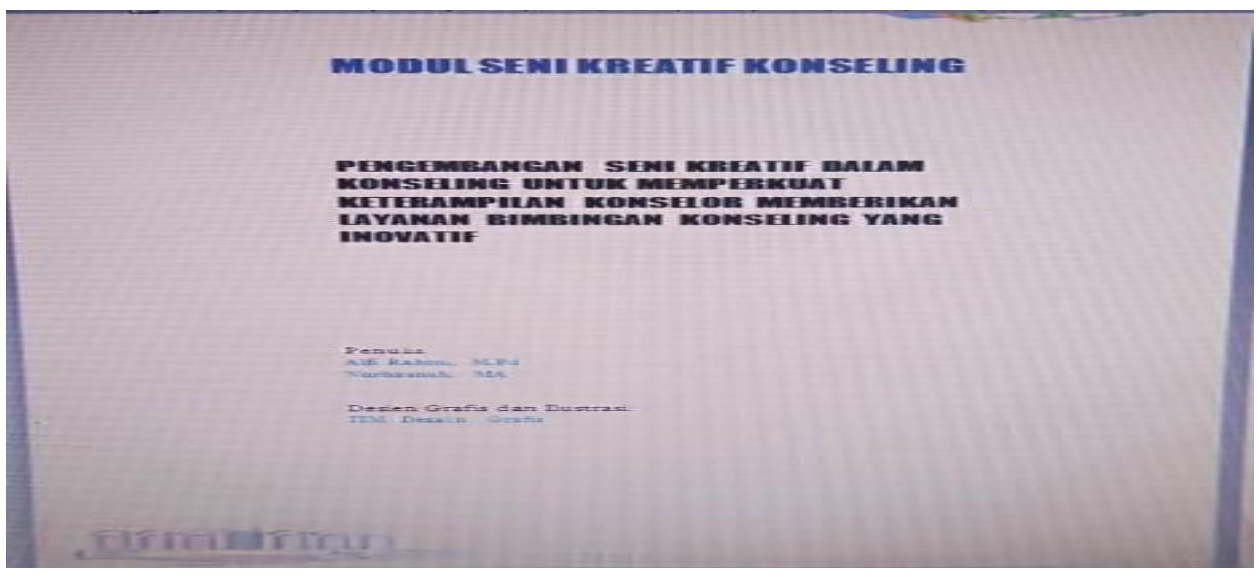

c. Kata Pengantar

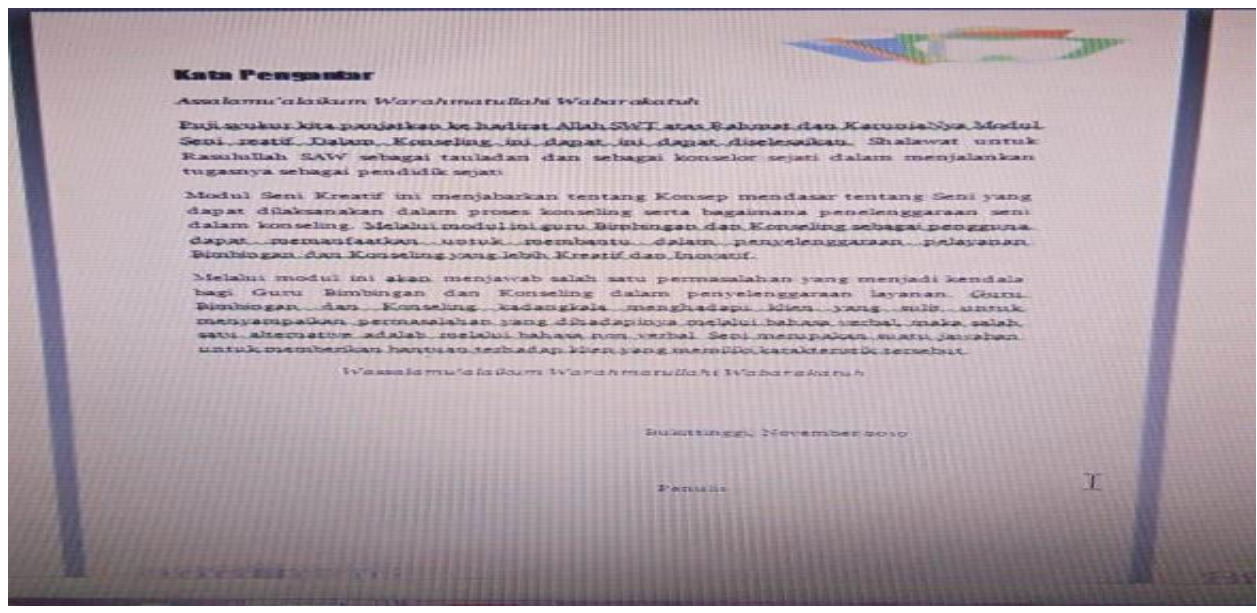


d. Daftar Isi

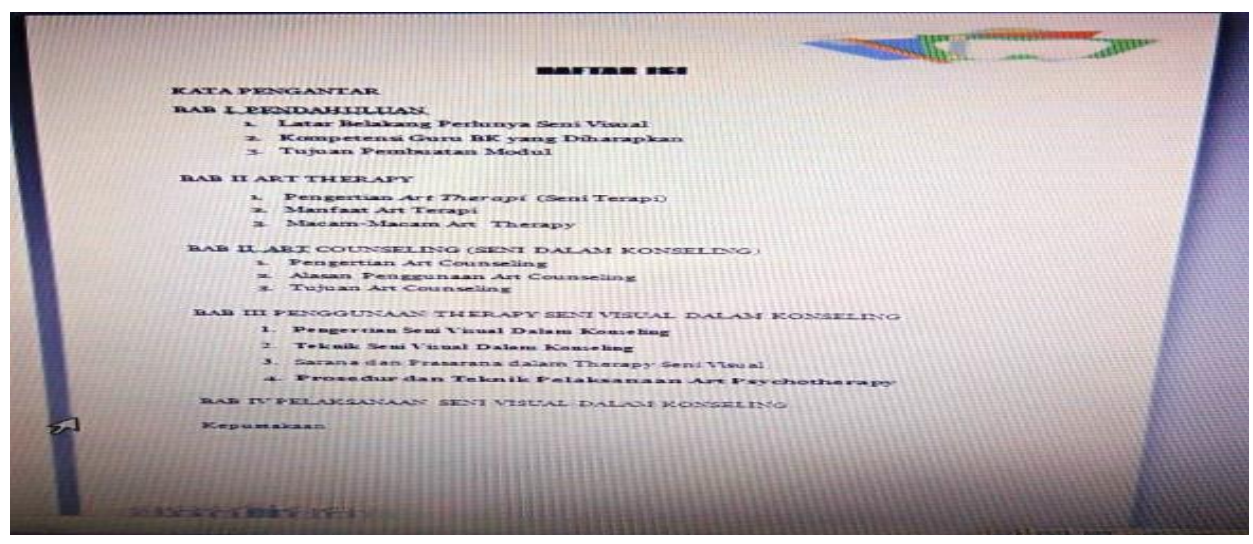

e. Tampilan Muka Antar Bab

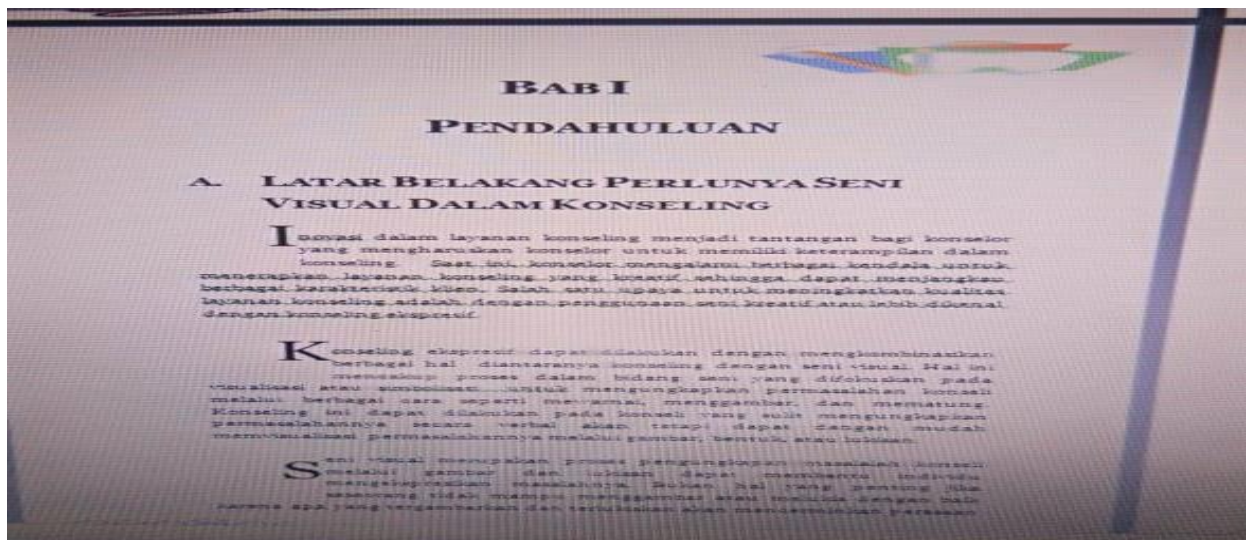

Untuk modul tahap II ini telah dilengkapi dengan beberapa seni visual yang dapat dilaksanakan dalam proses konseling yaitu:

a. Seni Visual Menggambar Bebas

Merupakan seni visual yang memberikan kesempatan kepada klien untuk mengekspresikan perasaan dan pikirannya yang dituangkan melalui gambar. Tahapan yang dilakukan oleh konselor dalam pelaksanaan konseling yaitu:

1) Tahap Awal yang bertujuan membangun hubungan konselor dengan klien.

2) Tahap Inti yang bertujuan meminta klien untuk menggambar dengan media yang telah disediakan oleh konselor

3) Tahap akhir yang bertujuan membuat kesimpulan hasil proses konseling 


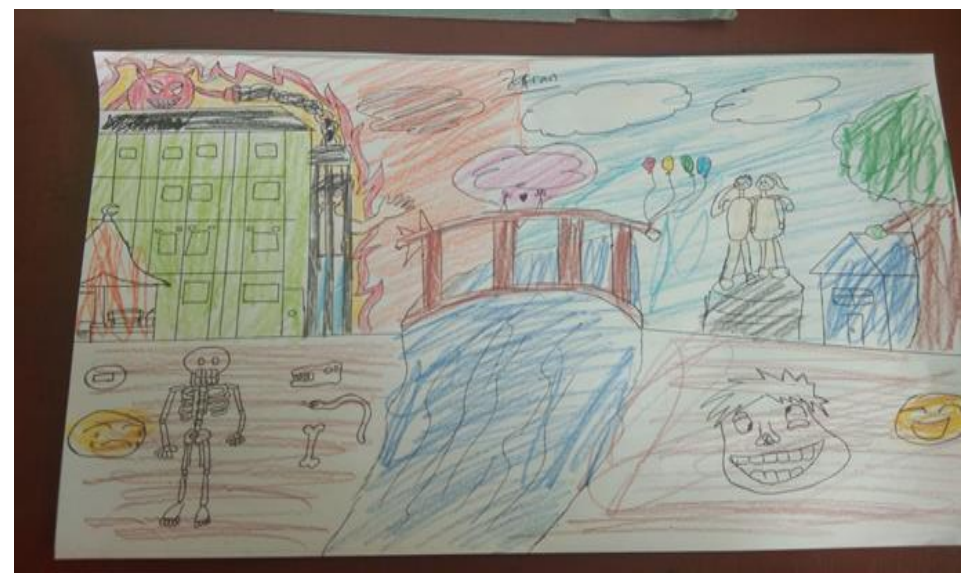

\section{b. Body Outline Drawing (Gambar Tubuh)}

Seni visual ini bertujuan untuk mengajak klien mengenali perasaan yang dirasakannnya dan reaksi pada tubuhnya. Tahapan yang dilakukan berupa:

1) Tahap Awal

Mempersiapkan bahan dan membangun hubungan awal anatar konselor dengan klien

2) Tahap Inti

Memberikan gambar outline tubuh pada klien dan merasakan pada tubuhnya yang sensitive dalam merasakan rasa senang, rasa sedih,rasa bahagia, rasa marah, serta dapat mengidentifikasi rasa yang lain (melalui warna pada bagian tubuh tersebut).

3) Tahap Akhir

Mengevaluasi kegiatan serta memberikan umpan balik yang positif
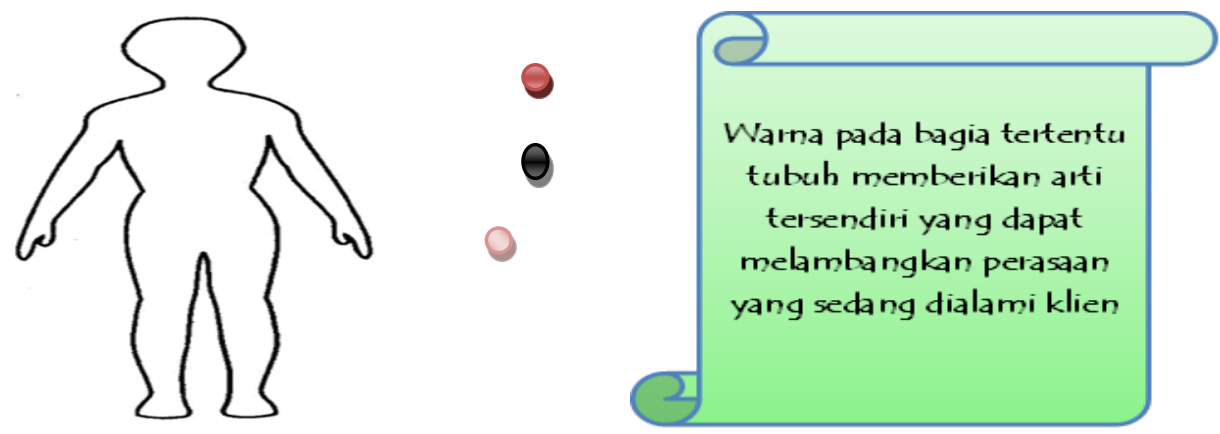

c. Solusi Bersama Menggambar Bersama (Sogama)

Merupakan kegiatan seni visual kreatif yang dilaksanakan secara 
berkelompok. Adapun tahapan yang dilakukan sebagai berikut:

1) Tahap awal

Membina hubungan awal anatar konselor dengan anggota kelompok

2) Tahap Inti

Tujuan memberikan penjelasan tentang pelaksanaan Sogama pada anggota kelompok. Adapun langkah-langkah dalam pelaksanaan Sogama yaitu:

a) Masing-masing anggota kelompok menggambarkan masalah yang dialaminya melalui kertas gambar yang telah disediakan.

b) Masing-masing anggota kelompok menceritakan gambar yang telah dibuatnya kepada semua anggota kelompok

c) Semua anggota kelompok memberikan solusi terhadap masalah yang dialami oleh anggota kelompo melalui gambar.
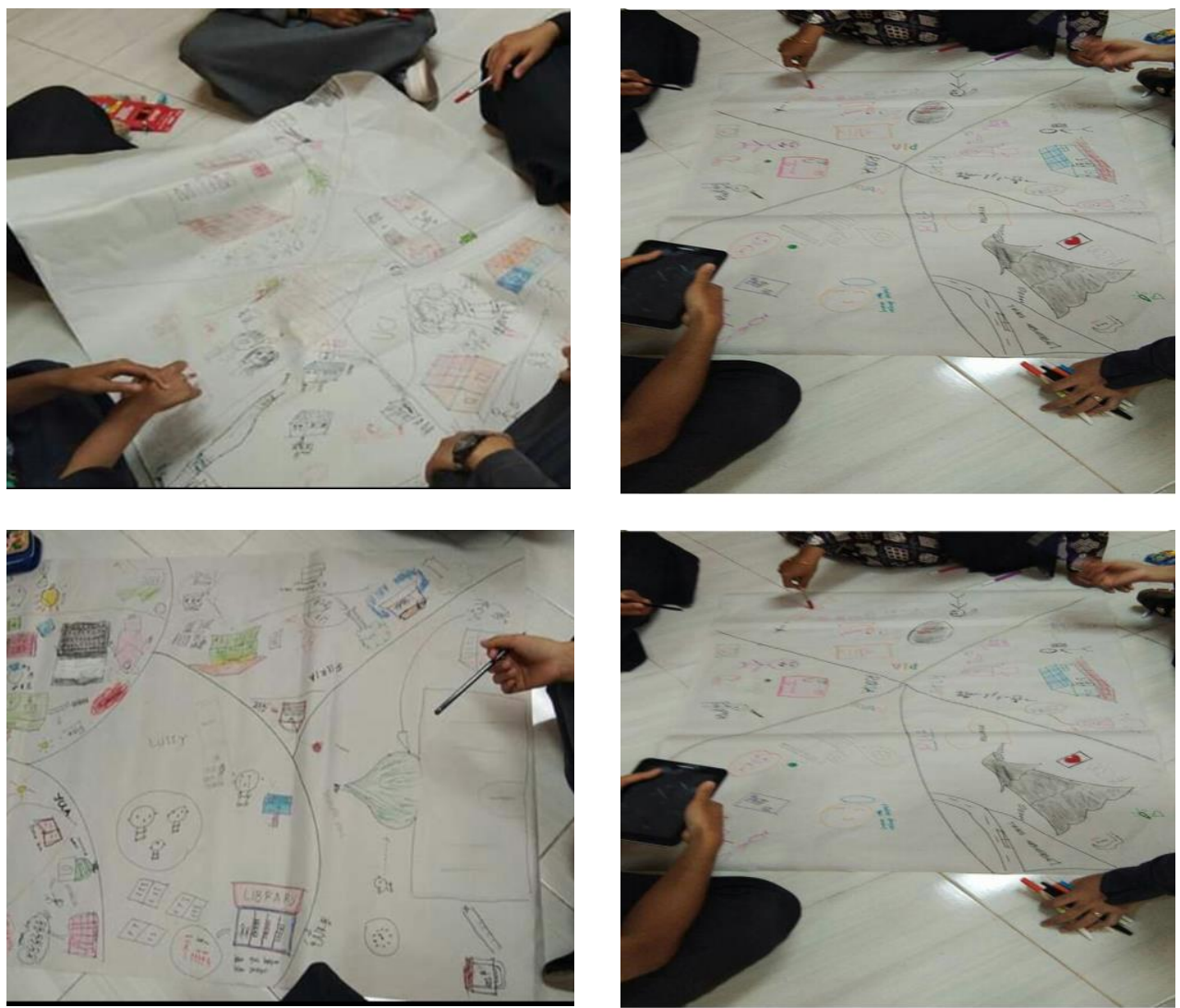

d. Ekspresi Emosi Ecoprint (E3)

Merupakan seni visual kreatif dalam mengekspresikan emosi melalui ecoprint. Klien yang mengalami masalah sulit dalam mengelola emosi dapat melatih diri dan melakukan suatu katarsis melalui ecoprint. 


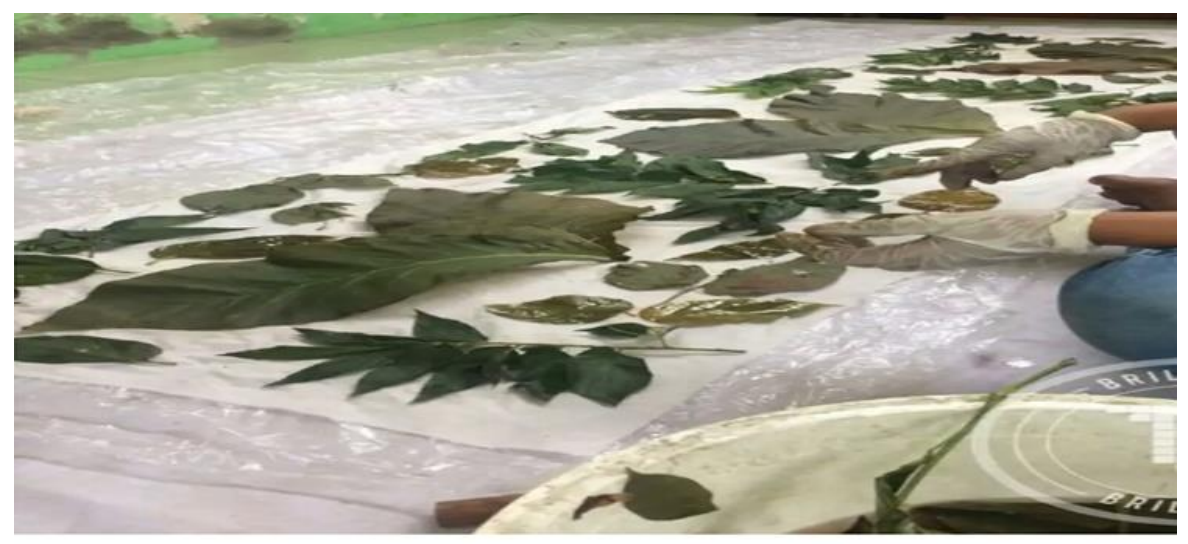

5. Uji coba lapangan

Uji lapangan yang dilakukan terhadap pada sekolah yang lebih luas yaitu 7 sekolah yaitu MTsN 6 Agam, Ponpes Parabek, MTI Candung, SMPN I Banuhampu, SMPN IV Koto, MTsN 2 Agam dan Ponpes Diniyah Pasie. Pada uji coba lapangan, guru BK diminta untuk mengimplementasikan seni visual kepada beberapa orang siswa dan santrin. Uji coba ini dilakukan untuk mengukur tingkat validitas dan partikalitas produk. Hasil uji conba adalah sebagai berikut :

a. Tingkat validitas

Pada tahap uji coba dilakukan uji validasi modul kepada guru BK dan Dosen BK dengan hasil pada tabel 3 sebagai berikut:

Tabel 3: Uji Validitas Modul Tahap II

\begin{tabular}{|c|c|c|c|c|}
\hline No & Aspek & Pernyataan & Rata-Rata & $\begin{array}{c}\text { Kriteria } \\
\text { Kevalidan } \\
\end{array}$ \\
\hline \multirow[t]{2}{*}{1} & \multirow[t]{2}{*}{ Bahasa } & $\begin{array}{l}\text { Bahasa yang digunakan } \\
\text { dalam modul dapat } \\
\text { dipahami dengan } \\
\text { mudah }\end{array}$ & 4,1 & \multirow{5}{*}{$\begin{array}{l}\text { Modul } \\
\text { dapat } \\
\text { digunakan } \\
\text { tanpa revisi } \\
\text { dengan } \\
\text { Nilai A }\end{array}$} \\
\hline & & $\begin{array}{l}\text { Modul Menggunakan } \\
\text { tata bahasa yang baik } \\
\text { dan benar }\end{array}$ & 4,2 & \\
\hline \multirow[t]{2}{*}{2} & \multirow[t]{2}{*}{$\begin{array}{l}\text { Penggunaan } \\
\text { Istilah dan } \\
\text { Simbol }\end{array}$} & $\begin{array}{l}\text { Penggunaan istilah } \\
\text { dalam modul konsisten } \\
\text { antar bagian }\end{array}$ & 4,1 & \\
\hline & & $\begin{array}{l}\text { Penggunaan notasi atau } \\
\text { symbol dalam modul } \\
\text { konsisten antar bagian }\end{array}$ & 4,2 & \\
\hline \multicolumn{3}{|c|}{ Total Rata Keseluruhan } & 16,6 & \\
\hline
\end{tabular}

Berdasarkan tabel 3 di atas dapat diketahui bahwa Modul Seni Visual 
dalam Konseling yang telah dirancang dapat digunakan tanpa revisi. Guru Bimbingan dan Konseling di sekolah dapat memanfaatkan modul ini sebagai panduan dalam menyelenggarakan konseling ekspresif khususnay pada seni visual.

Hasil uji praktikalitas dari modul yang peneliti kembangkan dapat dilihat tabel 4 sebagai berikut:

Tabel 4: Uji Praktikalitas Modul

\begin{tabular}{|c|c|c|c|}
\hline $\mathrm{No}$ & Pernyataan & Rata-Rata & $\begin{array}{c}\text { Kriteria } \\
\text { Pratikalitas }\end{array}$ \\
\hline 1 & $\begin{array}{l}\text { Modul ini Mudah digunakan dan } \\
\text { dipahami }\end{array}$ & 4.5 & Praktis \\
\hline 3 & Modul ini Sangat berguna & 5 & Sangat Praktis \\
\hline 4 & $\begin{array}{l}\text { Modul ini sesuai dengan indikator } \\
\text { dan mudah dipahami }\end{array}$ & 4.5 & Praktis \\
\hline 5 & Modul ini tepat sasaran & 5 & Sangat Praktis \\
\hline 6 & $\begin{array}{llll}\begin{array}{l}\text { Penyajian modul ini mudah } \\
\text { dipahami }\end{array} & & \\
\end{array}$ & 4,6 & Praktis \\
\hline 7 & $\begin{array}{l}\text { Penggunaan buku } \\
\text { Pengembangan Seni Kreatif dalam } \\
\text { Konseling untuk Memperkuat } \\
\text { Keterampilan } \\
\text { Memberikan Layanan Bimbingan } \\
\text { dan Konseling yang Inovatif } \\
\text { menumbuh kanselor } \\
\text { kemampuan konselor }\end{array}$ & 4,5 & Praktis \\
\hline & Total rata-rata & 4,01 & Praktis \\
\hline
\end{tabular}

6. Produk Modul Seni Kreatif dalam Konseling

Berdasarkan hasil uji coba lapangan yang lebih luas dengan melibatkan kelompok subyek lebih besar ini dimaksudkan untuk menentukan keberhasilan produk dalam mencapai tujuannya dan mengumpulkan informasi yang dapat dipakai untuk meningkatkan program atau produk untuk keperluan perbaikan pada tahap berikutnya.

\section{Penutup}

Berdasarkan hasil penelitian pengembangan Modul Seni Kreatif dalam konseling dapat disimpulkan bahwa guru Bimbingan dan konseling perlu melakukan suatu inovasi dalam pemberian layanan konseling kepada peserta didik. Salah satu inovasi yang dilakukan yaitu melalui penerapan seni kreatif visual. Untuk memandu pelaksanaan layanan konseling dengan seni visual, maka dibuatlah suatu panduan berupa modul seni kreatif konseling. Modul yang 
dirancang ini telah melalui fase uji coba teratas dan luas serta telah melalui kegiatan Focus Group Discussion. Berdasarkan hasil lapangan dapat disempurnakan modul seni kreatif ini.

Pelayanan konseling yang kreatif dan inovatif akan memberikan dampak positif bagi klien. Konseling kreatif dan inovatif ini dapat menjadi solusi bai guru Bimbingan dan konseling ketika menghadapi klien-klien yang mengalami kendala verbal dalam menyampaikan masalahnya. Untuk melengkapi kemampuan guru bimbingan dan konseling ini, maka perlu penguasaan lebih dalam untuk memahami gambar dan makna yang diungkapkan dari gambar yang dilukiskan oleh klien.

\section{Daftar Pustaka}

Alhadi, Said, and Wahyu Nanda Eka Saputra, 'Integrasi Seni Kreatif Dalam Konseling Dengan Pemanfaatan Seni Visual', JURNAL FOKUS KONSELING, 2017

Cathy Molchiadi, Hanbook of At Therapy (New York: Guilford Press, 2003)

Dede Rahmat Hidayat, Konseling Di Sekolah Pendekatan-Pendekatan Kontemporer (Jakarta: Prenadamedia Group, 2018)

epdiknas, Penataan Pendidikan Profesional Konselor Dan Layanan Bimbingan Dan Konseling DI Jalur Pendidikan Formal, 2008

Desvi Yanti Mukhtar, 'Efektivitas Art Therapy Untuk Meningkatkan Keterampilan Sosial Pada Anak Yang Mengalami Gangguan Perilaku', 2005

Fastari, Chandrania, ART PSYCHOTHERAPY GAMBAR

Gladding, Samuel T., The Creative Arts in Counseling: Fourth Edition, The Creative Arts in Counseling: Fourth Edition, 2015

Husni Abdillah, 'Penggunaan Seni Ekspresif Dalam Bimbingan Dan Konseling', Jurnal Bimbingan Dan Konseling Asosiasi Bimbingan Dan Konseling Indonesia Pengurus Daerah Provinsi Jawa Timur, 1.1 (2015), 43-49

I Made Tegeh dkk, Model Penelitian Pengembangan (Yoqyakarta: Graha Ilmu, 2014)

Karyanti, Dance Counseling, 1st edn (Yoqyakarta: Deepublish, 2018)

Peraturan Menteri Pendidikan Nasional, 'Standar Kualifikasi Akademik Dan Kompetensi Guru, Nomor 16 Tahun 2007 Tanggal 4 MeI 2007', Journal of Chemical Information and Modeling, 2007

Rahmadian, A. A, 'Kreativitas Dalam Konseling' (Bandung: UPI, 2011)

Wahyu Nanda Eka Saputra, Annisa Sofiana, 'Konseling Inovatif Berbantuan Seni Kreatif, Prosiding Seminar Nasional Bimbingan Dan Konseling, 2017 
180 | Islamic Counseling: Jurnal Bimbingan dan Konseling Islam, Vol. 4, No. 2, 2020 